\title{
Percepcija ravnatelja osnovnih škola o važnosti medijske pismenosti u primarnome obrazovanju
}

Prethodno priopćenie DOI 10.22522/cmr20190140 primlieno 20. travnja 2018.

UDK: 159.937:37.091.113

373.3

$003.02: 316.774$

$\ldots \ldots . . .0$

\section{Lana Ciboci}

Edward Bernays Visoka škola za komunikacijski menadžment, Zagreb, Hrvatska. E-adresa: Iciboci@gmail.com

\section{Tamara Gazdić-Alerić}

Učiteljski fakultet, Zagreb, Hrvatska. E-adresa: tamara.gazdic-aleric@ufzg.hr

\section{Igor Kanižaj}

Fakultet političkih znanosti, Zagreb, Hrvatska. E-adresa: ikanizaj@fpzg.hr

.........

\section{Sažetak}

Ravnatelji su jedni od ključnih nositelja odgojno-obrazovne djelatnosti u školama koji u suradnji sa školskim odborom, učenicima, roditeljima, stručnim suradnicima, ali i vanjskim partnerima mogu presudno utjecati na školski kurikul te kvalitetu i kvantitetu izvannastavnih aktivnosti. S obzirom na to da imaju ključnu ulogu u odgojno-obrazovnom procesu, začuđuje činjenica kako u Hrvatskoj gotovo da i nema istraživanja stavova ravnatelja o raznim pitanjima koja se tiču odgojno-obrazovnoga procesa, a dosad nije napravljeno niti jedno sustavno istraživanje o stavovima ravnatelja o medijskoj pismenosti, medijskom obrazovanju i medijskoj kulturi. Ta nas je činjenica dodatno motivirala da provedemo istraživanje u studenome 2016. u sklopu Stručnoga skupa Obrazovanje i licenciranje ravnatelja Hrvatske udruge ravnatelja osnovnih škola na uzorku od 198 ravnatelja osnovnih škola iz svih dijelova Republike Hrvatske kako bismo utvrdili stavove ravnatelja o važnosti medijske pismenosti u primarnome obrazovanju te da ujedno utvrdimo i to koliko su osnovne škole opremljene medijima, koliko često ravnatelji financijski podupiru dodatna usavršavanja nastavnika o medijima te organiziraju li škole izvannastavne edukacije o medijima za učenike, roditelje, nastavnike i stručne suradnike. Istraživanje je pokazalo kako većina ravnatelja, njih čak 57,3 \%, smatra da nakon završetka osnovne škole hrvatski učenici na temelju onoga što su naučili u školi nisu medijski pismene osobe te da u posljednjih nekoliko godina roditelji pokazuju povećan interes za medijsku pismenost. Unatoč tome, čak 43,8 \% ravnatelja ističe da nikad u posljednjih godinu dana nisu organizirali izvannastavna predavanja o medijima za roditelje, a čak svaki četvrti ravnatelj ističe da se u njihovoj školi nikad ne održavaju predavanja o medijima za nastavnike i stručne suradnike. Pokazalo se i da škole još uvijek nisu dobro tehnički opremljene, što je preduvjet za provedbu medijskoga obrazovanja, budući da je tek 44,2 \% ravnatelja istaknulo da u njihovoj školi u svakoj učionici postoje računalo i projektor. Budući da ravnatelji bitno utječu na kvalitetu nastavnoga rada, i oni sami trebali bi imati redovita usavršavanja vezana uz medijsku pismenost kako bi bili pravodobno upoznati s rezultatima najnovijih istraživanja iz toga područja te informirani o novim dostignućima vezanima uz medije koji se brzo razvijaju.

Ključne riječi: medijsko obrazovanje, medijska pismenost, osnovna škola, ravnatelji 


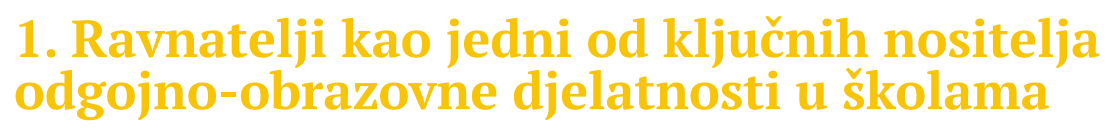

Brze promjene koje se događaju u znanosti, tehnici, tehnologiji, gospodarstvu i ostalim područjima društvenoga života zahtijevaju trajno unapređenje školskoga sustava, odnosno postavljaju odgoju i obrazovanju nove zahtjeve, što dovodi do potrebe za njegovim stalnim vrednovanjem i mijenjanjem. U Hrvatskoj je u tijeku priprema i provedba cjelovite kurikulske reforme odgojno-obrazovnoga sustava koja predstavlja prvu mjeru kojom je započela realizacija Strategije obrazovanja, znanosti i tehnologije koja je prihvaćena u Hrvatskome saboru u listopadu 2014. Reforma odgojno-obrazovnoga sustava prije svega pretpostavlja visoku kompetentnost onih koji poučavaju djecu i učenike kao i visoku kompetentnost onih koji odlučuju o organizaciji odgojno-obrazovnoga rada i nastave, $u$ čemu jednu od ključnih uloga imaju ravnatelji. Prema tome, reforma odgojno-obrazovnoga sustava pretpostavlja kompetentnost i odgovornost odgojitelja, učitelja, nastavnika, profesora, stručnih suradnika, dekana i ravnatelja te ostalih važnih sudionika i korisnika obrazovanja - roditelja, djece, učenika, članova lokalne i regionalne zajednice, socijalnih partnera i drugih. Kompetentnost nositelja odgojno-obrazovne djelatnosti u predškolskim ustanovama, osnovnim i srednjim školama osigurava se ponajprije kvalitetnim inicijalnim obrazovanjem na visokoškolskim ustanovama, a ujednačenost i standardizirana njihova osposobljenost i obrazovanost osigurava se uvođenjem licenciranja (mjerodavnosti), što podrazumijeva njihov sustavan, redovit i stalan stručni razvoj. U Zakonu o odgoju $i$ obrazovanju u osnovnoj i srednjoj školi (NN, 126/2012, čl. 115, st. 1) stručan razvoj definiran je ovim riječima: „...učitelji, nastavnici, stručni suradnici i ravnatelji školske ustanove imaju pravo i obvezu trajno se stručno osposobljavati i usavršavati kroz programe koje je odobrilo Ministarstvo“.U stavku 2.istoga članka objašnjeno je kako se pod stalnim stručnim osposobljavanjem i usavršavanjem iz stavka 1. podrazumijeva „pojedinačno i organizirano usavršavanje u matičnoj znanosti u području pedagogije, didaktike, obrazovne psihologije, metodike, informacijsko-komunikacijskih tehnologija, savjetodavnog rada, upravljanja, obrazovnih politika i drugih područja relevantnih za učinkovito i visokokvalitetno obavljanje odgojno-obrazovne djelatnosti u školskim ustanovama“. No, predmet ovoga rada nije profesionalizacija rada ravnatelja, kako je sugerirano u Strategiji obrazovanja, znanosti i tehnologije iz 2014., već mogućnosti i uloge ravnatelja u poticanju razvoja novih kurikula koji se odnose na programe medijske pismenosti. Anđelka Varga, Rahaela Peko i Diana Vican (2016, str. 49) u svom radu donose pregled transformacije uloge ravnatelja 
te $u$ analizi pokazuju kako se 2011. godine u ključnim strateškim dokumentima naglašava „osposobljenost za primjenu kurikulumskog pristupa “ u kontekstu implementacije (2010) te navode kako bi ravnatelji trebali promicati sposobnost drugih (učenika, učitelja i drugih suradnika) u zajednici učenja čime bi utjecali na „kvalitetu procesa nastave i kurikuluma“. Dalje ističu da „premda se utjecaj ravnatelja na učenička postignuća često promatra kao neizravan, on zato nije zanemariv. Naprotiv, upravo je ravnatelj stručnjak koji kompetentnim odlučivanjem i djelovanjem može najsveobuhvatnije koordinirati promjene života škole, a time poboljšati i svakodnevni učenički doživljaj odgoja i obrazovanja u školi“. Iz svega navedenoga vidljivo je kako je uloga ravnatelja ključna za funkcioniranje školske ustanove, za provedbu kvalitetnih nastavnih i izvannastavnih aktivnosti te da je kao takva bitna i u razvoju i implementiranju promjena u odgojno-obrazovnome sustavu. Uloga ravnatelja prepoznata je i u istraživanjima koja se odnose na primjenu informacijsko-komunikacijske tehnologije u nastavi. William J. Pelgrum (1993) je u svojem istraživanju pokazao kako pozitivan stav ravnatelja prema primjeni računala $u$ nastavi može utjecati na učitelje i nastavnike naglašavanjem važnosti učenja koje se temelji i na uporabi računala (prema Pollizi, 2011, str. 115). Jedno od značajnijih istraživanja $u$ tom području koje su proveli Christella Dawson i Glenda C. Rakes (2003) potvrdilo je kako su ravnatelji važni kada je riječ o razvoju novih programa koji se temelje na tehnologiji. Dokazali su kako će razvoj takvih programa u velikoj mjeri ovisiti o količini i vrsti edukacije koju su prošli sami ravnatelji (prema Pollizi, 2011, str. 115). I drugi su autori u svojim istraživanjima utvrdili kako su edukacije ravnatelja važne jer osim što ih senzibiliziraju, podižu njihovo samopouzdanje, što olakšava uključivanje programa u kurikul (usp. Serhan 2007, str. 46 prema Pollizi, 2011, str. 115).

\subsection{Zakonska regulativa i uloga ravnatelja u odgojno- obrazovnom sustavu}

U hrvatskom odgojno-obrazovnom sustavu ravnatelji bez sumnje imaju jednu od ključnih uloga. Njihove su obveze i odgovornosti vrlo jasno definirane zakonom, pravilnicima i drugim propisima. No, oni su daleko više od samih upravitelja sustava u lokalnoj zajednici $\mathrm{s}$ vidljivim razlikama u radnim opterećenjima, sustavima iz kojih dolaze te s brojem ljudi kojima upravljaju. Uz učitelje i stručne suradnike, ravnatelji su ključni nositelji odgojnoobrazovne djelatnosti u školama (usp. Nastavni plan i program za osnovnu školu, 2006). Ravnatelji u suradnji sa školskim odborom, učenicima, roditeljima, stručnim suradnicima, ali i vanjskim partnerima te lokalnom zajednicom, odnosno osnivačem mogu presudno utjecati na školski kurikul te kvalitetu i kvantitetu izvannastavnih aktivnosti. 
Zakoni i drugi pravni propisi definiraju glavne obveze i odgovornosti ravnatelja u odnosu na druge sudionike u odgojno-obrazovnom sustavu. Godine 2011. Ministarstvo znanosti, obrazovanja i športa donijelo je dokument na nacionalnoj razini - Nacionalni okvirni kurikulum za predškolski odgoj i obrazovanje te opće obvezno i srednjoškolsko obrazovanje na kojem se temelji odgoj i obrazovanje na predškolskoj, osnovnoškolskoj i srednjoškolskoj razini. U njemu se donosi okvir promjena obrazovnoga sustava od vrtića do fakulteta $u$ budućnosti te se na više mjesta naglašava kako je za takve promjene potrebna visoka kompetentnost nositelja odgojno-obrazovnoga rada koja pretpostavlja „izradbu sustavnih programa za osposobljavanje učitelja, nastavnika, stručnih suradnika i ravnatelja za primjenu kurikulumskoga pristupa“ (2011, str. 12). Iako je izrada Nacionalnoga kurikuluma Republike Hrvatske trebala biti jedna od prvih mjera kojom je trebalo započeti realizaciju Strategije obrazovanja, znanosti i tehnologije (2014), odnosno cjelovitu kurikulsku reformu obrazovanja, Nacionalni kurikulum Republike Hrvatske još je u pripremnoj fazi, što je navedeno i na mrežnoj stranici Ministarstva znanosti i obrazovanja ${ }^{1}$. Prema tome, do donošenja novoga Nacionalnoga kurikuluma Republike Hrvatske na snazi je navedeni Nacionalni okvirni kurikul iz 2011.

Na razini škole svake se godine donose dva temeljna dokumenta koja definiraju odgojnoobrazovni rad, prava i obveze sudionika te definiraju ostale aktivnosti u funkciji odgojnoobrazovnoga rada i poslovanja školske ustanove - školski kurikul i godišnji plan i program rada. Ta dva dokumenta donosi školski odbor na prijedlog nastavničkoga vijeća i ravnatelja. Godišnji plan i program rada školske ustanove donosi se na osnovi nastavnoga plana i programa, koji donosi nadležno ministarstvo, i školskoga kurikula. Godišnjim planom i programom rada školske ustanove utvrđuju se, uz mjesto, vrijeme, način i izvršitelje poslova, i planovi rada ravnatelja, učitelja, odnosno nastavnika te stručnih suradnika, kao i plan stručnog osposobljavanja i usavršavanja u skladu s potrebama škole. Formalnopravno stvoreni su temeljni preduvjeti da ravnatelj u suradnji sa školskim odborom može u velikoj mjeri utjecati na razvoj školskoga kurikula, prilagođavajući ga potrebama škole. I Zakonom o odgoju i obrazovanju u osnovnoj i srednjoj školi (NN, 126/12, čl. 125) ističe se da ravnatelj „u suradnji s učiteljskim, odnosno nastavničkim, odnosno odgajateljskim vijećem, predlaže školski kurikulum“. Školski kurikul utvrđuje dugoročni i kratkoročni plan i program škole s izvannastavnim i izvanškolskim aktivnostima, a donosi se na temelju nacionalnog kurikula i nastavnoga plana i programa koji, kao što smo rekli, donosi

1 https://mzo.hr/hr/rubrike/nacionalni-kurikulum 
nadležno ministarstvo. U slučaju primarnoga obrazovanja riječ je o, u ovom trenutku još uvijek važećem, Nastavnome planu i programu za osnovnu školu iz 2006. godine. Školski kurikul određuje nastavni plan i program izbornih predmeta, izvannastavne i izvanškolske aktivnosti i druge odgojno-obrazovne aktivnosti, programe i projekte. U pojedinim pravilnicima izrijekom se navodi i važnost prevencije i preventivnih programa protiv nasilja u školama, pri čemu se kao sve češći izazov pojavljuje prevencija vršnjačkoga nasilja koje se ostvaruje posredstvom novih medija. U Pravilniku o načinu postupanja odgojno-obrazovnih radnika školskih ustanova u poduzimanju mjera zaštite prava učenika te prijave svakog kršenja tih prava nadležnim tijelima stoji kako je školska ustanova obvezna „implementirati postojeće preventivne i intervencijske programe te prema potrebama razvijati nove uz odgovarajući model njihova praćenja i vrednovanja“"(NN 132/2013: čl. 3, st. 4).

U brojnim hrvatskim školama uspješno se realiziraju preventivni programi u suradnji s lokalnom zajednicom, pri čemu se uloga ravnatelja pokazuje od nemjerljive važnosti. Upravo na primjeru vršnjačkoga nasilja posredstvom novih medija te raznih drugih oblika rizičnoga ponašanja ili općenito nasilja putem novih medija možemo vidjeti potrebu snažnijeg djelovanja školskih odbora, ravnatelja i stručnih suradnika u izgradnji novih preventivnih programa koji ulaze $\mathrm{u}$ područje medijske pismenosti. Nerijetko se upravo inicijativom ravnatelja pokreće suradnja i s udrugama civilnog društva u području preventivnoga djelovanja. I u Zakonu o odgoju i obrazovanju u osnovnoj i srednjoj školi (NN, 126/2012, čl. 4, st. 1) stoji da su ciljevi odgoja i obrazovanja u školskim ustanovama: „osigurati učenicima stjecanje temeljnih (općeobrazovnih) i stručnih kompetencija, osposobiti ih za život i rad u promjenjivom društveno-kulturnom kontekstu prema zahtjevima tržišnog gospodarstva, suvremenih informacijsko-komunikacijskih tehnologija i znanstvenih spoznaja i dostignuća“.

U Hrvatskoj je objavljen vrlo mali broj znanstvenih radova koji se odnose na ispitivanje stavova ravnatelja osnovnih i srednjih škola, a prema dostupnim istraživanjima, nažalost, dosad nije objavljeno sustavno istraživanje o stavovima ravnatelja o medijskoj pismenosti, medijskom obrazovanju i medijskoj kulturi, što nas je dodatno motiviralo da provedemo ovo istraživanje. Istraživana je uloga ravnatelja u motiviranju učitelja (Matijević Šimić, 2011), rukovodeća uloga ravnatelja u školi (Blažević, 2014), uloga ravnatelja u koncepcijama promjena odgojnoobrazovnog sustava Republike Hrvatske (Varga, Peko, Vican, 2016), ali i socijalna kompetencija i zvanje ravnatelja osnovnih i srednjih škola (Janković, 2012) te sadržaj, oblici i metode uspješne suradnje ravnatelja i pedagoga u osnovnoj školi (Šturlić, Silov, 2014). 


\section{Interes i potreba za medijskim obrazovanjem}

Hrvatski sabor je 2014. donio nacionalnu Strategiju obrazovanja, znanosti i tehnologije u kojoj je izrijekom istaknuto kako je pri izradi kurikulskih dokumenata važno osigurati „...uvođenje novih sadržaja kojima će se razvijati informacijska, financijska i medijska pismenost“. I djeca i mladi iskazali su interes i potrebu za medijskim obrazovanjem kako bi razvili kompetenciju medijske pismenosti. Prema istraživanju koje je 2013. godine zajedno s Ipsos Pulsom provelo Društvo za komunikacijsku i medijsku kulturu (DKMK) utvrđeno je kako 67,6 \% učenika u dobi od 10 do 19 godina smatra kako bi medijsko obrazovanje trebalo biti uključeno u obrazovni sustav (Ciboci, Kanižaj, Labaš, 2015, str. 173). Slično misle i roditelji. U istraživanju stavova roditelja predškolske djece koje je 2013. godine provedeno među 837 roditelja predškolske djece u Gradu Zagrebu 68,1 \% roditelja smatra kako je medijsko obrazovanje potrebno od najranije dobi, a 69,1 \% smatra kako je s medijskim obrazovanjem potrebno započeti već u vrtiću (Ciboci, Kanižaj, Labaš, 2014, str. 62).

O potrebi uvođenja novih programa medijske pismenosti govore i rezultati istraživanja EU Kids Online Hrvatska koje je u listopadu i studenom 2017. provela agencija Ipsos Puls među 1017 djece u dobi od 9 do 17 godina. Istraživanje je pokazalo kako je u tijekom 2017. godine više od pola djece koja su sudjelovala $u$ istraživanju u dobi od 9 do 17 godina primilo povređujuću ili neprimjerenu poruku. Pritom je takvu poruku primilo više od $1 / 3$ djece u dobi od 9 do 11 godina, gotovo $1 / 2$ djece u dobi od 12 do 14 godina te gotovo $3 / 4$ djece u dobi od 15 do 17 godina (EU Kids Online Hrvatska, 2017). Prema istom istraživanju svako četvrto dijete $u$ dobi od 9 do 14 godina te svako treće dijete u dobi od 15 do 17 godina u potpunosti je ili uglavnom zabrinuto za svoju privatnost na internetu. Navedeni podatci i stavovi djece i mladih upućuju na nedvojbenu potrebu novih programa medijske pismenosti. Osim djece, $u$ istraživanju su sudjelovali i njihovi roditelji. Pokazalo se da većina roditelja, njih čak $80 \%$, smatra da bi u škole trebalo uvesti poseban predmet koji bi se bavio samo medijskim odgojem djece te bi većina njih, kada bi se radilo o izbornom predmetu, svoje dijete upisala na njega (EU Kids Online Hrvatska, 2017).

Medijska kultura u važećem Nastavnome planu i programu za osnovnu školu (2006) jedno je od četiri nastavna područja predmeta Hrvatski jezik. Zadaće toga nastavnoga područja su: osposobljavanje za komunikaciju s medijima: kazalištem, filmom, radijem, tiskom, stripom, računalom; primanje (recepcija) kazališne predstave, filma, radijske i televizijske 
emisije; osposobljavanje za vrednovanje radijskih i televizijskih emisija te filmskih ostvarenja. Nastava medijske kulture, prema istraživanju koje su proveli Malović i sur. (2014), u prosjeku se održava 12 sati godišnje s tim da je već ukupna satnica materinskoga jezika 2006. godine smanjena. Satnica Hrvatskoga jezika od 1. do 6. razreda iznosi 5 sati tjedno, dakle 175 sati godišnje, a u 7.i 8. razredu samo 4 sata tjedno, što je 140 sati godišnje i ona prema mišljenjima stručnjaka iz toga područja nije dostatna ni za nastavu jezika i književnosti, a ujedno i zaostaje za satnicama materinskoga jezika razvijenih europskih država (usporedbe radi, hrvatski učenici imaju 4 do 5 sati materinskoga jezika tjedno, Francuzi 10, planiraju je povećati na 12, Mađari 6 do 8, a Finci čak 14 sati) (Gazdić-Alerić, 2018). Usto teme koje su propisane Nastavnim planom i programom za osnovnu školu (2006) ne obuhvaćaju suvremene medije. Elektronički se mediji na primjer od prvoga pa sve do osmoga razreda spominju samo četiri puta, a novim je medijima posvećena samo jedna nastavna jedinica (Gazdić-Alerić, Alerić, 2017, str. 215).

Tablica 1. Sadržaji medijske kulture po razredima

\begin{tabular}{|c|c|}
\hline 1. Razred & Animirani film, lutkarska predstava, knjižnica \\
\hline 2. Razred & Filmska priča, kazalište, televizija, dječji časopisi \\
\hline 3.Razred & Dječji film, radijska emisija, knjižnica - korištenje enciklopedije \\
\hline 4. Razred & $\begin{array}{l}\text { Dokumentarni film, usporedba filma s književnim djelom, računalo, knjižnica - } \\
\text { služenje rječnikom i školskim pravopisom }\end{array}$ \\
\hline 5. Razred & Mediji, filmski rodovi, animirani film, tisak, kazalište \\
\hline 6. Razred & Filmska izražajna sredstva, mreža (internet), strip \\
\hline 7. Razred & Igrani film, televizijske emisije, radio, knjižnica \\
\hline 8. Razred & $\begin{array}{l}\text { Scenarij, knjiga snimanja; dokumentarni film, Zagrebačka škola crtanoga filma, u } \\
\text { potrazi za knjigom }\end{array}$ \\
\hline
\end{tabular}

Osim što su sadržaji medijske kulture zastarjeli te ih je potrebno osuvremeniti i modernizirati, istraživanja pokazuju i da nastavni materijali iz Hrvatskoga jezika premalo potiču razvoj kritičkog mišljenja kod djece u tom području te nedovoljno podučavaju djecu kako da sami kreiraju vlastite medijske sadržaje i time postanu aktivni sudionici u suvremenome društvu (Ciboci, 2018a). Stoga ne čudi što istraživanja pokazuju da učenici u hrvatskim školama posjeduju visoku razinu znanja o medijima, no da im nedostaju vještine kritičkoga promišljanja i stvaranja medijskih sadržaja (Ciboci, 2018b). Promjene su nužne i u sustavu visokog obrazovanja, osobito na onim studijima na kojima se obrazuju 
budući nastavnici Hrvatskoga jezika, jer i oni sami naglašavaju da im nedostaje znanja u tom području, da su premalo o tome učili tijekom studija, ali i da se tehnika i tehnologija razvijaju jako brzo, pa su im konstantno potrebna usavršavanja u tome području (Ciboci, 2018a) te da ključnu ulogu u tome procesu mogu i trebaju imati ravnatelji odgojnoobrazovnih ustanova omogućavanjem nastavnicima, osobito u kontekstu financijske podrške, dodatnih usavršavanja.

U ovom radu krećemo od pretpostavke kako ravnatelji imaju važnu ulogu u kreiranju školskoga kurikula te mogu presudno utjecati na kvalitetu i kvantitetu izvannastavnih aktivnosti u kojima vidimo prostor za nove sadržaje i programe medijske pismenosti. U razvoju takvih programa i ostvarivanju suradnje s ključnim dionicima na lokalnoj, ali i nacionalnoj razini vidimo presudnu ulogu ravnatelja. Iako se $u$ hrvatskim školama gotovo na svakodnevnoj razini mogu pronaći primjeri u kojima se već i dio aktivnosti temelji na iznajmljivanju prostora udrugama i institucijama za provođenje raznih izvannastavnih programa (među kojima u posljednje vrijeme sve češće razni programi kodiranja i primjene informacijsko-komunikacijskih tehnologija²), smatramo kako prethodno navedena istraživanja upućuju na potrebu razvoja primarno programa medijske pismenosti za što postoji vrlo jasno izražen stav šire javnosti koji se temelji na reprezentativnim istraživanjima.

\section{Uloga ravnatelja u poticanju medijske pismenosti u hrivatskim školama}

Nakon što smo u teorijskom dijelu rada istaknuli važnost ravnatelja unutar hrvatskoga obrazovnog sustava, osobito u procesu kreiranja školskih politika, u istraživačkom smo dijelu rada proveli istraživanje kojim smo ispitali njihove stavove o različitim aspektima medijske pismenosti u hrvatskim školama. Glavni je cilj istraživanja bio utvrditi stavove ravnatelja osnovnih škola o važnosti medijske pismenosti u primarnome obrazovanju, a sekundarni su ciljevi bili istražiti koliko su osnovne škole tehnički opremljene medijima, koliko često ravnatelji financijski podupiru dodatna usavršavanja nastavnika o medijima te organiziraju li škole izvannastavnu edukaciju o medijima za učenike, roditelje, nastavnike i stručne suradnike. Na temelju postavljenih ciljeva, proizašle su sljedeće hipoteze:

2 Dalje: IKT 
$H_{1}$ : Ravnatelji hrvatskih osnovnih škola ne smatraju da je medijska pismenost važan dio primarnog obrazovanja.

$\mathrm{H}_{2}$ : Ravnatelji rijetko potiču izvannastavna predavanja o medijima za učenike, roditelje i nastavnike.

U istraživanju je sudjelovalo 198 ravnatelja osnovnih škola iz čitave Hrvatske, od toga 36,8 \% osoba muškog i 63,2 \% osobe ženskoga spola. U istraživanju je sudjelovalo $21,8 \%$ ravnatelja iz Grada Zagreba, 14,9 \% iz Splitsko-dalmatinske, 8,5 \% iz Međimurske, 7,4 \% iz Vukovarsko-srijemske, 5,3 \% iz Brodsko-posavske i Zagrebačke županije, 4,8 \% iz Istarske i Varaždinske, 4,3 \% iz Zadarske i Karlovačke, 3,7 \% iz Osječko-baranjske, 2,7 \% iz Primorskogoranske i Krapinsko-zagorske, 2,1 \% iz Dubrovačko-neretvanske, Šibensko-kninske i Sisačko-moslavačke županije, 1,1 \% iz Požeško-slavonske i Koprivničko-križevačke te 0,5 \% iz Bjelovarsko-bilogorske te Ličko-senjske županije. Prosječna dob ispitanika je 49 godina, a prosječni radni staž ispitanika 22 godine. Uzorak je bio prigodan. Naime, istraživanje je provedeno uz pomoć potpore znanstvenim i umjetničkim istraživanjima Sveučilišta u Zagrebu kao dio projekta Razvoj kompetencija medijske pismenosti učenika osnovnih škola voditeljice Tamare Gazdić-Alerić u studenome 2016. u sklopu Stručnoga skupa Obrazovanje i licenciranje ravnatelja Hrvatske udruge ravnatelja osnovnih škola.

\subsection{Rezultati istraživanja i rasprava}

\subsubsection{Opremljenost škola medijima}

Za kvalitetnu provedbu medijske pismenosti u školama i stjecanje medijskih kompetencija među učenicima nužna je adekvatna tehnička opremljenost škola. Istraživanje je pokazalo da čak 60,7 \% ravnatelja u potpunosti ili uglavnom smatra da je njihova škola dobro tehnički opremljena medijima, no svaki je treći ravnatelj istaknuo da njegova škola nije dobro tehnički opremljena. Pritom je čak 76,8 \% ravnatelja istaknulo da u njihovoj školi internetska veza postoji u svakoj učionici, no unatoč tome tek je 44,2 \% ravnatelja istaknulo da u njihovoj školi u svakoj učionici postoje računalo i projektor, a što je jedan od ključnih preduvjeta za primjenu medija u nastavi i kvalitetno medijsko opismenjavanje u školama. No, osim za stjecanje medijskih kompetencija, tehnička opremljenost škola medijima važna je i za unapređenje kvalitete nastavnog procesa jer istraživanja pokazuju da primjena medija u nastavi može obogatiti živote djece, promijeniti nezdrave vrste ponašanja, poticati inkluziju i toleranciju, smanjiti razliku između društvenih slojeva, 
pridonijeti razvoju i civilnom društvu, potaknuti maštu i kreativnost te proširiti obrazovanje i znanje (Kolucki, Lemish, 2013).

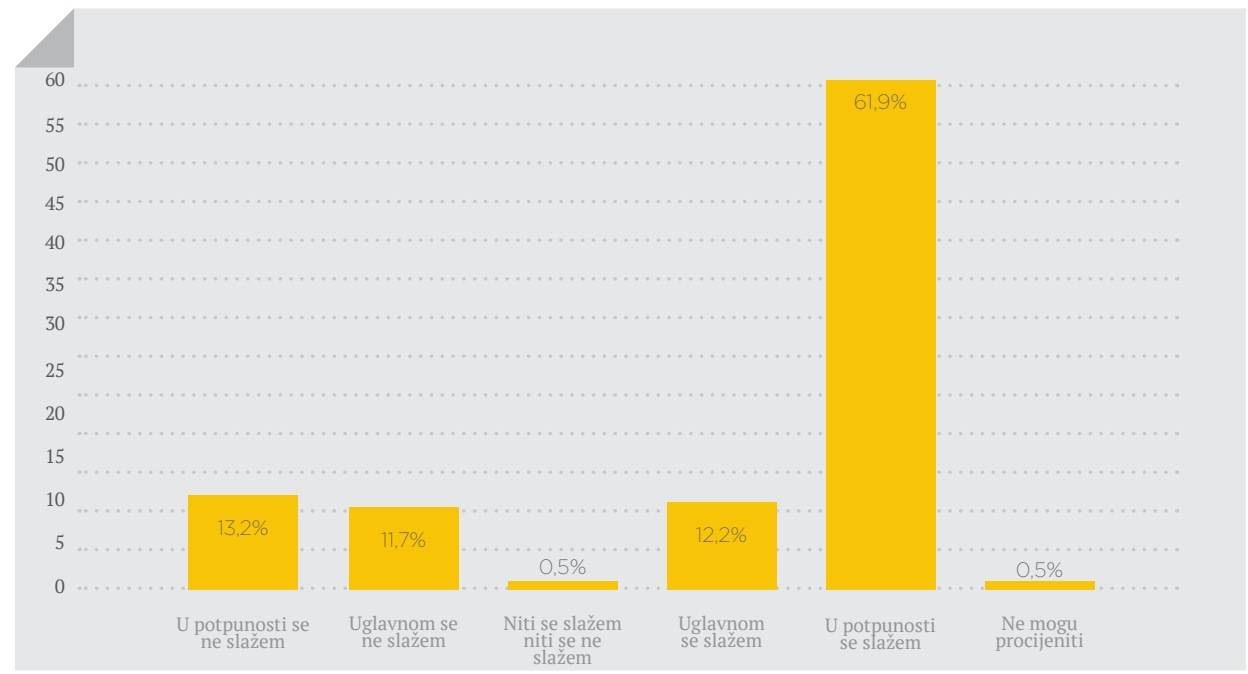

Grafikon 1. Primjena medija u nastavi može poboljšati kvalitetu nastave - stavovi ravnatelja (\%) (N = 197)

No, ravnatelji koji su sudjelovali u istraživanju još uvijek nisu dovoljno upoznati sa svim prednostima medija u obrazovnome procesu. Naime, svaki četvrti ravnatelj ne smatra da primjena medija u nastavi može poboljšati kvalitetu nastave, što pokazuje da nisu dovoljno informirani o svim pozitivnim stranama primjene medija u nastavnome procesu.

\subsubsection{Percepcija medijske pismenosti među ravnateljima osnovnih škola}

Da važnost medijske pismenosti još uvijek nije prepoznata među svim ravnateljima koji imaju ključnu ulogu u kreiranju školskih politika, pokazuju rezultati istraživanja prema kojima se svaki peti ravnatelj uopće ne slaže s tvrdnjom da je medijska pismenost neophodna u 21. stoljeću (vidi grafikon 2). 


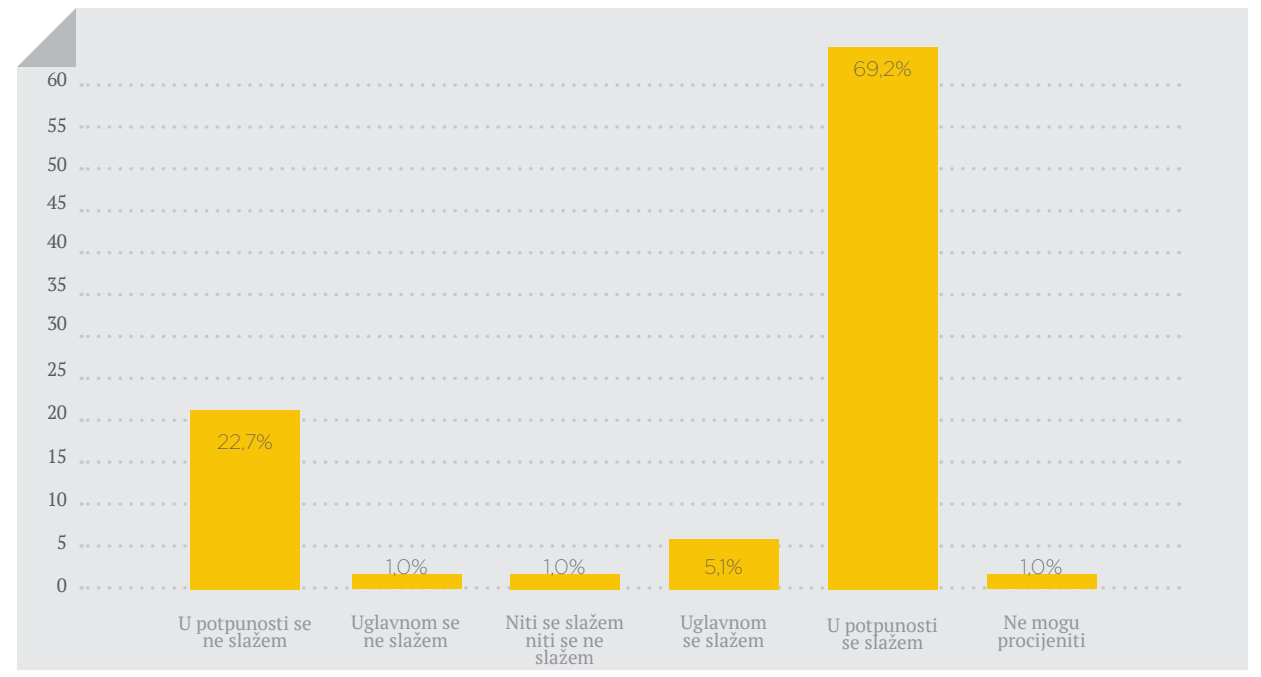

Grafikon 2. Medijska pismenost neophodna je u 21. stoljeću - stavovi ravnatelja (\%) (N=198)

Takvi podaci i ne iznenađuju ako se uzmu u obzir rezultati koji su pokazali kako značajan broj ravnatelja uopće i ne zna što je medijska pismenost. Naime, na pitanje koje su karakteristike medijski pismene osobe, odnosno koja znanja i vještine takva osoba mora posjedovati, mnogi su ravnatelji medijsku pismenost izjednačili s informatičkom pismenošću: „Računalne vještine“; „Određeni stupanj informatičke pismenosti“; „Rad na računalu, pametna ploča, e-katalozi, e-knjige“; „Koristiti se uređajima i aplikacijama koje oni podržavaju“; „Poznavanje rada i programa na računalu, poznavanje engleskog jezika (djelomično), jezika računala“; „Korištenje interneta, pisanje dokumenata (Word, Excel), izrada prezentacija (PowerPoint), zaštita podataka“; „Računala, tj. informatička pismenost“; „Koristiti računalo u svakom pogledu, korištenje e-maila, obavezno poznavanje Worda“; „Informatičke kompetencije, kritičko mišljenje, korištenje resursa i softwera u nastavi“'. Tek je manji broj ravnatelja istaknuo važnost kritičkog promišljanja i stvaranja vlastitih medijskih sadržaja, što samo pokazuje da ni sami ravnatelji nisu dovoljno upoznati s pojmom medijske pismenosti niti što ona podrazumijeva te su stoga edukacije u tome području prijeko potrebne i njima samima. Iako prepoznati kao jedan od najvažnijih dionika u tome procesu, oni zapravo na razini Hrvatske nisu imali mogućnost sudjelovanja u sustavnim programima medijskog opismenjavanja. 


\subsubsection{Stavovi nastavnika o modelu medijske kulture u hrvatskim školama}

Kao što smo istaknuli u teorijskome dijelu rada, medijska je pismenost u Hrvatskoj dio predmeta Hrvatski jezik, odnosno nalazi se u Medijskoj kulturi koja čini jedno od njegova četiri nastavna područja. Jedan od ciljeva ovog istraživanja bio je istražiti i što sami ravnatelji misle o medijskoj kulturi, osobito u kontekstu kvalitetnog medijskog opismenjavanja u hrvatskim školama. Čak 59,7 \% ravnatelja se u potpunosti ili uglavnom ne slaže s tvrdnjom da je model medijske kulture u hrvatskim školama prilagođen brzom razvoju medija i novih tehnologija. Većina ravnatelja osnovnih škola smatra da je hrvatski model medijske kulture nužno osuvremeniti. Naime, tako se izjasnilo čak 78,7 \% ravnatelja. Isto tako $45,1 \%$ njih se u potpunosti ili uglavnom ne slaže $\mathrm{s}$ tvrdnjom da model medijske kulture $u$ hrvatskim školama u potpunosti priprema djecu za kritičko služenje medijskim sadržajima. No, istodobno se gotovo dvije petine ravnatelja slaže s navedenom tvrdnjom iako istraživanja (Ciboci, 2018) pokazuju da model medijske kulture najveće nedostatke pokazuje upravo u poticanju na kritičko promišljanje.

Tablica 1. Stavovi ravnatelja o medijskoj kulturi u osnovnoj školi (\%)

\begin{tabular}{|c|c|c|c|c|c|c|c|}
\hline & $\mathbf{N}$ & $\begin{array}{l}\text { Potpuno } \\
\text { se ne } \\
\text { slažem }\end{array}$ & $\begin{array}{l}\text { Djelomično } \\
\text { se ne } \\
\text { slažem }\end{array}$ & $\begin{array}{l}\text { Niti se } \\
\text { slažem } \\
\text { niti se ne } \\
\text { slažem }\end{array}$ & $\begin{array}{l}\text { Djelo- } \\
\text { mično } \\
\text { se slažem }\end{array}$ & $\begin{array}{l}\text { Potpuno } \\
\text { se slažem }\end{array}$ & $\begin{array}{l}\text { Ne mogu } \\
\text { procije- } \\
\text { niti }\end{array}$ \\
\hline $\begin{array}{l}\text { Model medijske } \\
\text { kulture u hrvatskim } \\
\text { školama u } \\
\text { potpunosti priprema } \\
\text { djecu za kritičko } \\
\text { služenje medijskim } \\
\text { sadržajima. }\end{array}$ & 195 & 15,4 & 29,7 & 14,9 & 27,2 & 10,3 & 2,6 \\
\hline $\begin{array}{l}\text { Model medijske } \\
\text { kulture u hrvatskim } \\
\text { školama prilagođen } \\
\text { je brzom razvoju } \\
\text { medija i novih } \\
\text { tehnologija. }\end{array}$ & 196 & 30,6 & 29,1 & 12,2 & 21,9 & 3,6 & 2,6 \\
\hline $\begin{array}{l}\text { Nakon završetka } \\
\text { osnovne škole } \\
\text { hrvatski učenici su } \\
\text { na temelju onoga } \\
\text { što su naučili u školi } \\
\text { medijski pismene } \\
\text { osobe. }\end{array}$ & 194 & 28,4 & 28,9 & 12,9 & 24,2 & 3,6 & 2,1 \\
\hline $\begin{array}{l}\text { Hrvatski model } \\
\text { medijske } \\
\text { kulture nužno je } \\
\text { osuvremeniti. }\end{array}$ & 197 & 14,2 & 4,1 & 2,5 & 14,2 & 64,5 & 0,5 \\
\hline
\end{tabular}


No, najbolji pokazatelj neučinkovitosti postojećeg medijskog opismenjavanja u hrvatskim školama jest podatak prema kojem većina ravnatelja, njih čak 57,3 \%, smatra da nakon završetka osnovne škole hrvatski učenici na temelju onoga što su naučili u školi nisu medijski pismene osobe. Navedeni podatak pokazuje da čak i oni koji sudjeluju u kreiranju školskih politika smatraju da je trenutačni model medijskog obrazovanja u Hrvatskoj neadekvatan i da djecu u hrvatskim školama ne priprema na kvalitetan način na suživot s medijima.

\subsubsection{Organiziranje izvannastavnih predavanja o medijima za učenike, roditelje, nastavnike i stručne suradnike}

Dosadašnja istraživanja o kvaliteti medijskog obrazovanja u Hrvatskoj pokazuju da je riječ o zastarjelom programu u kojem se novim medijima posvećuje jako malo pozornosti, a i ne posvećuju mu svi nastavnici jednaku pozornost (Ciboci, Osmančević, 2015). Stoga je ovim istraživanjem bilo važno utvrditi i koliko često škole organiziraju izvannastavna predavanja o medijima. Naime, prethodna istraživanja poput Mapping media literacy practices and actions in EU 28 (EAO, 2017), koja se provode na razini Europske unije, pokazuju kako se kroz brojne aktivnosti udruga provode programi medijske pismenosti, a kao jedan od primjera s aktivnim organizacijama civilnog društva ističe se i Hrvatska.

Prilikom provedbe istraživanja 17,8 \% ravnatelja priznalo je da u njihovoj školi nikad nisu održana izvannastavna predavanja za učenike. Njih 40,3 \% istaknulo je da se u njihovoj školi takva predavanja održavaju jednom godišnje, 27,7 \% jednom u polugodištu, dok je tek $14,1 \%$ ravnatelja reklo da se takva predavanja održavaju nekoliko puta u polugodištu. Osim za učenike, takva su predavanja prijeko potrebna i roditeljima kojima je danas, kada su nove tehnike i tehnologije u pitanju, više nego ikad potrebna pomoć. Naime, čak dvije trećine roditelja djece u dobi od 9 do 17 godina u Hrvatskoj smatra da se djeca bolje služe tehnikom od njih samih (EU Kids Online Hrvatska, 2017). Ovo je istraživanje pokazalo da čak 53,4 \% ravnatelja osnovnih škola ističe da u posljednjih nekoliko godina roditelji pokazuju povećani interes za medijsku pismenost. Unatoč tome, čak 43,8 \% ravnatelja ističe da u posljednjih godinu dana nikad nisu organizirali izvannastavna predavanja o medijima za roditelje. Njih 39,1 \% istaknulo je da se u njihovoj školi takva predavanja održavaju jednom godišnje, 15,6 \% jednom u polugodištu, a tek 1,6 \% ravnatelja istaknulo je da u svakom polugodištu organiziraju predavanja o medijima za roditelje. 
Istraživanja (Ciboci, Osmančević, 2015; Ciboci, 2018) su pokazala i da sami učitelji Hrvatskoga jezika koji provode medijsku kulturu u osnovnim školama ističu kako su im potrebna dodatna usavršavanja o medijima jer nisu stekli dovoljno znanja o medijima tijekom svoje izobrazbe, ali i da se tehnika toliko brzo razvija, da su im potreba stalna usavršavanja. Unatoč tome, svaki četvrti ravnatelj ističe da se u njihovoj školi nikad ne održavaju predavanja o medijima za nastavnike i stručne suradnike, a njih 47,3 \% ističe da se u njihovoj školi takva predavanja održavaju jednom godišnje, 20,2 \% jednom u polugodištu, a 7,4 \% ravnatelja ističe da takva predavanja za nastavnike i stručne suradnike održavaju nekoliko puta u polugodištu.

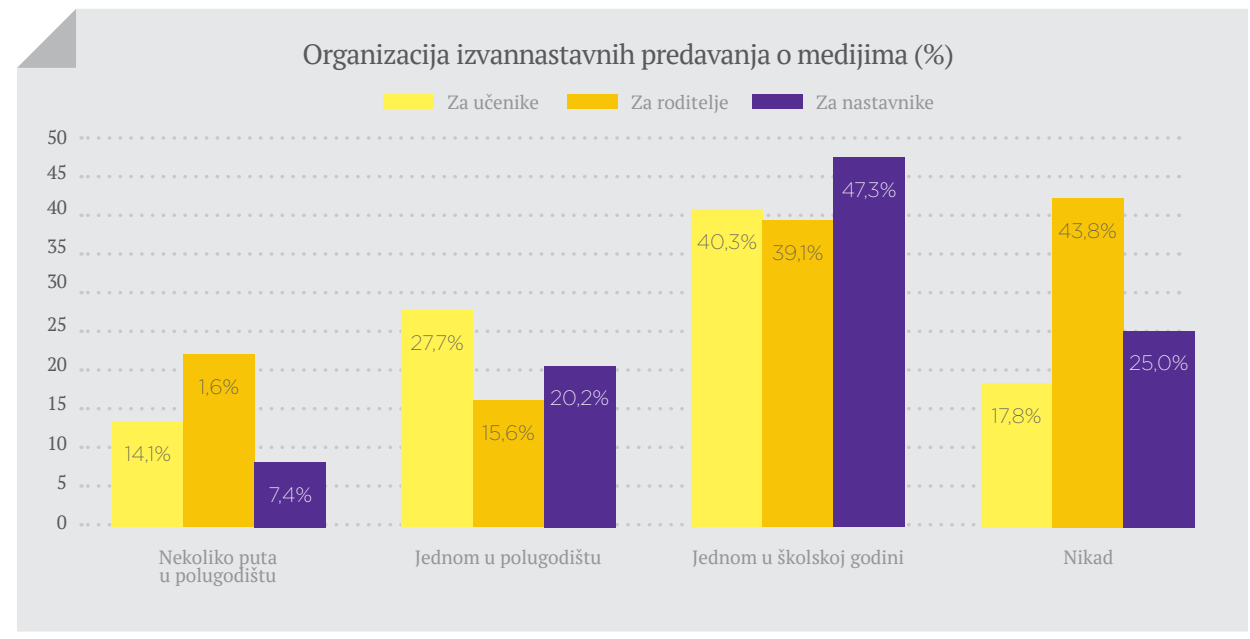

Grafikon 3. Organizacija izvannastavnih predavanja o medijima (\%) $(\mathrm{N}=198)$

Ravnatelji imaju važnu ulogu i u dodatnom usavršavanju nastavnika izvan škole. Naime, za mnoga je usavršavanja potrebno izdvojiti određena financijska sredstva, zbog čega je ovim istraživanjem bilo važno utvrditi i podupiru li ravnatelji, $u$ financijskom smislu, redoviti odlazak svojih nastavnika na dodatne edukacije o medijima. Istraživanje je pokazalo da to čini 61,9 \% ravnatelja, njih 5,5\% ne, a 33 \% ponekad. Ravnatelji koji to ne čine redovito kao najčešći su razlog naveli nedostatak financijskih sredstava općenito u školi, pa i za edukacije nastavnika, ali i nezainteresiranost nastavnika za takva usavršavanja te općenito nedovoljan broj kvalitetnih usavršavanja o medijima. 


\section{Zaključak}

Ravnatelji odgojno-obrazovnih ustanova imaju važnu ulogu u kreiranju školskih politika, prepoznavanju novih trendova u obrazovanju kao i znanja i kompetencija koja djeci postaju neophodna u suvremenom društvu. Među tim kompetencijama svakako su i one medijske. Budući da su rezultati ovoga istraživanja pokazali da su i sami ravnatelji nezadovoljni sustavom medijskog obrazovanja u Hrvatskoj, ali da i njima samima nedostaje znanja o medijima te da mnogi ne prepoznaju važnost medijske pismenosti, nužno je u budućnosti:

Osigurati usavršavanja o medijskoj pismenosti za ravnatelje - posjedovanje medijskih kompetencija postalo je neophodno u 21. stoljeću za sve članove društva, pa tako i za ravnatelje. Zato je iznimno važno osigurati ravnateljima redovita usavršavanja na temelju kojih će biti upoznati s najnovijim istraživanjima i promjenama u tome području, osobito što se tiče razvoja tehnike i tehnologije koje mogu pridonijeti kvaliteti nastave te kako bi postali svjesni uloge medije u dječjim životima, pozitivnom i negativnom utjecaju različitih medijskih sadržaja na djecu, ali i na odrasle, odnosno kako bi uočili pozitivnu ulogu medija u poboljšanju kvalitete nastavnoga procesa.

Opremiti škole medijima i medijskim uređajima - istraživanje je pokazalo da mnoge škole još uvijek nisu dovoljno tehnički opremljene, a upravo je to ključni preduvjet za provedbu medijskog obrazovanja. Sva bi djeca u Hrvatskoj, neovisno o prebivalištu, volji lokalne samouprave i menadžerskim sposobnostima ravnatelja, trebala imati jednako kvalitetno obrazovanje, kako opće, tako i ono medijsko. I u Strategiji obrazovanja, znanosti i tehnologije (2014: 41) ističe se kako se teži „uspostavi odgojno-obrazovnog sustava koji svakoj osobi omogućuje stjecanje znanja, vještina i stavova potrebnih za uspješan život u suvremenom društvu“.

Osuvremeniti sadržaje medijske kulture u nastavi Hrvatskoga jezika - kao što pokazuju i druga prethodna istraživanja (Ciboci, Osmančević, 2014; Ciboci, 2018a), i sami ravnatelji smatraju da je trenutačni model medijskog obrazovanja u Hrvatskoj zastario, da ga je nužno modernizirati. Budući da u nedovoljnoj mjeri razvija kritičko razmišljanje kod učenika, potrebno ga je osmisliti i u tome dijelu. 
Organizirati predavanja o medijima za roditelje i nastavnike - budući da sami roditelji ističu da se djeca koriste tehnikom i tehnologijom bolje od njih samih te da su medijski pismenija (EU Kids Online Hrvatska, 2017), što ne mora biti točno, važno je u budućnosti osobitu pozornost posvetiti roditeljima i njihovu medijskom opismenjavanju. Ključnu ulogu u tome trebaju imati same škole koje bi redovito trebale organizirati edukacije i usavršavanja za roditelje u svim onim područjima koja imaju važan utjecaj na njihovu djecu, pa tako i u području medija. Pritom je, naravno, takva usavršavanja potrebno organizirati i za same nastavnike te im pokazati kako uporaba medija može pridonijeti kvaliteti nastave.

Sve te smjernice ključne su za kvalitetan razvoj medijskog obrazovanja u Hrvatskoj kakvo zaslužuju sva djeca, neovisno o prebivalištu. Budući da djeca uz medije iz godine u godinu provode sve više vremena, može se očekivati da će i utjecaj koji će mediji imati na njih biti sve veći. Stoga je važno pripremiti ih na vrijeme za sve ono što mediji donose, a to prije svega znači da s medijskim obrazovanjem treba početi od najranije dobi, još u vrtiću, a nastaviti u osnovnoj školi i dalje u obrazovnoj vertikali. Ključnu ulogu u određivanju školskih kurikula imaju ravnatelji koji bi trebali imati redovita usavršavanja vezana uz medijsku pismenost kako bi bili pravodobno upoznati s rezultatima najnovijih istraživanja iz toga područja te informirani o novim dostignućima vezanima uz medije i informacijskokomunikacijske tehnologije koje se brzo razvijaju koji se brzo razvijaju. 


\section{Popis literature}

- Blažević, I. (2014). Rukovodeća uloga ravnatelja u školi. Školski vjesnik: časopis za pedagogijsku teoriju i praksu, 63 (1-2), 7-21.

- Ciboci, L. (2018a). Vrjednovanje programa medijske kulture u medijskom opismenjivanju učenika osnovnih škola (doktorska disertacija.) Zagreb: Filozofski fakultet, Sveučilište u Zagrebu.

- Ciboci, L. (2018b). Medijska pismenost učenika osmih razreda u Zagrebu. Medijske studije, 9 (17), 23-46.

- Ciboci, L., Kanižaj, I., Labaš, D. (2014). Media Education From the Perspective of Parents of Preschool Children: Challenges and Trends in Free Time Media Use. Medijska istraživanja, 20 (2), 53-68.

- Ciboci, L., Kanižaj, I., Labaš, D. (2015). Public Opinion Research as a Prerequisite for Media Education Strategies and Policies, 171-182. U: Sirkku, K., Kupiainen, R. (ur.), Reflection on Media Education Futures. International Clearinghouse on Children, Youth and Media, Nordicom, University of Gothenburg.

- Ciboci, L., Osmančević, L. (2015). Kompetentnost nastavnika hrvatskoga jezika za provođenje medijske kulture u hrvatskim osnovnim školama, 121-138. U: Car, V., Turčilo, L., Matović, M. (ur.), Medijska pismenost - preduvjet za odgovorne medije. Zbornik radova s 5. regionalne znanstvene konferencije Vjerodostojnost medija. Sarajevo: Fakultet političkih nauka Univerziteta u Sarajevu.

- Dawson, C., Glenda, C. R. (2003). The Influence of Principals' Technology Training on the Integration of Technology into Schools. Journal of Research on Technology in Education, 36 (1), 29-49.

- Gazdić-Alerić, T., Alerić, M. (2017). Primjedbe i prijedlozi vezani uz Nacionalni kurikulum nastavnoga predmeta Hrvatski jezik s osvrtom i na Nacionalni kurikulum ranog i predškolskog odgoja i obrazovanja, 212-217. U: Prilozi za raspravu o obrazovnoj i kurikulnoj reformi; Kritike i vizije; Recenzije članova Znanstvenoga vijeća za obrazovanje i školstvo Hrvatske akademije znanosti i umjetnosti. Zagreb: Hrvatsko pedagoško-književni zbor.

- Gazdić-Alerić, T. (2018). Svi se «razumiju» u nogomet i hrvatski jezik. Školske novine, 15, 7-9.

- Janković, M. (2012). Socijalna kompetencija i zvanje ravnatelja osnovnih i srednjih škola. Andragoški glasnik, 16 (2), 117-129.

- Matijević Šimić, D. (2011). Uloga ravnatelja u motiviraju učitelja. Napredak, 152 (2) 227-248.

- Nacionalni okvirni kurikulum za predškolski odgoj i obrazovanje te opće obvezno i srednjoškolsko obrazovanje (2011). Zagreb: Ministarstvo znanosti, obrazovanja i športa. Dostupno na http://mzos.hr/datoteke/Nacionalni_okvirni_kurikulum. pdf. Preuzeto 5. prosinca 2017.

- Nastavni plan i program za osnovnu školu (2006). Zagreb: Ministarstvo znanosti, obrazovanja i športa.

- Pravilnik o načinu postupanja odgojno-obrazovnih radnika školskih ustanova u poduzimanju mjera zaštite prava učenika te prijave svakog kršenja tih prava nadležnim tijelima, NN 132/13.

- Pelgrum, W. J. (1993). Attitudes of School Principals and Teachers Towards Computers: Does it Matter What They Think? Studies in Educational Evaluation, 19 (2), 199-212

- Pollizi, G. (2011). Measuring School Principal's Support for ICT Integration in Palermo, Italy. Journal of Media Literacy Education, 3 (2), 113-122.

- Strategija obrazovanja, znanosti i tehnologije, NN 124/14

- Serhan, D. (2007). School Principals' Attitudes Towards the Use of Technology: United Arab Emirates Technology Workshop. The Turkish Online Journal of Educational Technology 6 (2), 42-46.

- Šturlić, N., Silov, M. (2014). Sadržaj, oblici i metode uspješne suradnje ravnatelja i pedagoga u osnovnoj školi. Andragoški glasnik, 18 (1), 59-70.

- Varga, R., Peko, A., Vican, D. (2016). Uloga ravnatelja u koncepcijama promjena odgojno-obrazovnog sustava Republike Hrvatske. Život i škola, LXII (1), 39-50.

- Zakon o odgoju i obrazovanju u osnovnoj i srednjoj školi, NN 126/12 


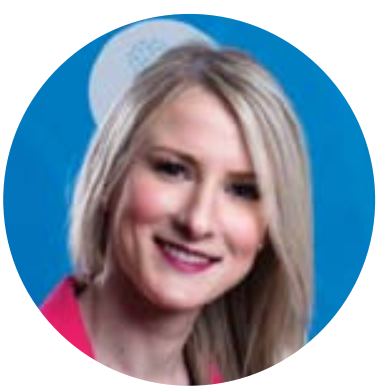

Lana Ciboci

Doc. dr. sc. Lana Ciboci prodekanica je za znanost i upravljanje kvalitetom na Edward Bernays Visokoj školi za komunikacijski menadžment. Predaje kao vanjska suradnica i na Hrvatskim studijima te na Učiteljskom fakultetu Sveučilišta u Zagrebu. Potpredsjednica je Društva za komunikacijsku i medijsku kulturu, udruge civilnog društva koja je posvećena neformalnom medijskom obrazovanju djece, roditelja, nastavnika i stručnih suradnika u školama. Predsjednica je Organizacijskog i supredsjednica Programskog odbora znanstvene konferencije Communication Management Forum. Voditeljica je Bernaysova znanstveno-istraživačkog laboratorija. Članica je hrvatskoga tima velikih međunarodnih projekata - EU Kids Online, Mind Over Media i The Digital International Media Literacy eBook Project (DIMLE).

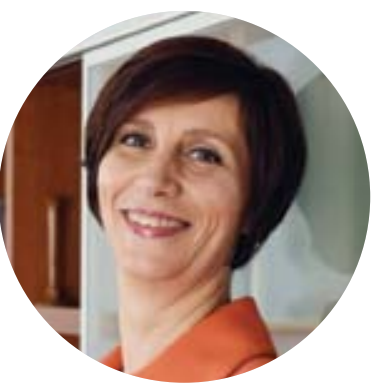

\section{Tamara Gazdić-Alerić}

Izv. prof. dr. sc. Tamara Gazdić-Alerić diplomirala je na Filozofskome fakultetu i na Fakultetu političkih znanosti Sveučilišta u Zagrebu. Doktorirala je iz područja humanističkih znanosti, grane lingvistike.Zaposlena je na Učiteljskom fakultetu Sveučilišta u Zagrebu, Katedri za hrvatski jezik i književnost, medijsku i scensku kulturu. Od 2012. do 2015. obnašala je dužnost prodekanice za znanost, umjetnost i međunarodnu suradnju. Predaje kao vanjska suradnica i na Filozofskom fakultetu u Zagrebu. Od 1995. do 2003. radila je na HRT-u u Informativnopolitičkoj redakciji, Redakciji obrazovnog i dječjeg programa te Redakciji za kulturu, znanost i religiju. Zamjenica je glavnoga urednika znanstvenoga časopisa Napredak Hrvatskoga pedagoško-književnog zbora i članica uredništva Hrvatskoga časopisa za odgoj i obrazovanje Učiteljskoga fakulteta. Članica je Znanstvenoga vijeća za obrazovanje i školstvo HAZU te voditeljica Radne sekcije za hrvatski jezik. Od 2017. do 2019. bila je voditeljica Radne sekcije za nastavu humanističkih i društvenih predmeta i umjetnost. Godine 2017. dobitnica Nagrade za znanost i tehnologiju Mreže hrvatskih žena/ The Croatian Women's Network $u$ kategoriji „Utjecajne hrvatske žene“/ Croatian Women of Influence Award.

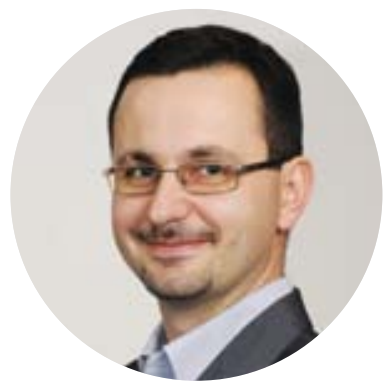

Igor Kanižaj

Izv. prof. dr. sc. Igor Kanižaj zaposlen je na Fakultetu političkih znanosti Sveučilišta u Zagrebu, na Odsjeku za novinarstvo i medijsku produkciju. Od 2014. do 2016. obnašao je dužnost prodekana za znanost i međunarodnu suradnju. Suautor je UNESCOVE Pariške deklaracije o medijskoj i informacijskoj pismenosti u digitalno doba iz 2014. godine. Član je Vijeća za djecu RH i pročelnik Odjela za medije Matice hrvatske te predsjednik Radne skupine za ECTS bodove Sveučilišta u Zagrebu. Jedan je od pokretača Komunikološke škole Matice hrvatske. Zajedno sa suradnicima kroz projekt Djeca medija Društva za komunikacijsku i medijsku kulturu provodio je, nadzirao ili organizirao 1000 radionica o medijskoj pismenosti za 19.000 polaznika (djecu, roditelju, nastavnike i stručne suradnike). Pokretač je studentskih novina Global i član uredništva interdisciplinarnog znanstvenog časopisa Medijske studije. 